\title{
Hubungan Antara Trait Kepribadian Maladaptif Manajer dan Kualitas Leader-Member Exchange: Studi pada Manajer First line di PT X dan Bawahannya
}

\author{
Relationship between Maladaptive Personality Traits in \\ Managers and the Quality of Leader-member Exchange: \\ A Study in First line Managers in X Company \\ and Their Subordinates
}

\author{
Adrian $^{1}$, Justinus Budi Santoso ${ }^{1,2}$ \\ ${ }^{1}$ Fakultas Psikologi Universitas Katolik Indonesia Atma Jaya \\ ${ }^{2}$ Email: justinus.budi@atmajaya.ac.id
}

\begin{abstract}
KATA KUNCI Kepemimpinan, Trait Kepribadian Maladaptif, Gangguan Kepribadian, Relasi Pemimpin dan Bawahan, Five-factor Model.

KEYWORDS Leadership, Maladaptive Personality Trait, Personality Disorder, Leader and Subordinate Relationship, Five-factor Model.
\end{abstract}

ABSTRAK Individu dengan trait kepribadian maladaptif yang belum sampai taraf gangguan kepribadian masih bisa berfungsi, bahkan sukses dalam kehidupan sehari-hari. Di lingkungan kerja, pemimpin dengan trait kepribadian maladaptif berpotensi memiliki masalah dalam hubungan interpersonal dengan rekan kerjanya. Penelitian ini bertujuan untuk mengetahui hubungan antara trait kepribadian maladaptif dengan hubungan pimpinan dengan bawahannya berdasarkan pendekatan leader-member exchange (LMX). Partisipan penelitian ini adalah 72 diad atau pasangan manajer first line di PT X dengan staf yang menjadi bawahannya. Seorang manajer dapat memiliki lebih dari satu bawahan sehingga jumlah manajer hanya 21 orang. Trait kepribadian maladaptif pada manajer diukur dengan Personality Inventory for DSM-5 Brief Form (PID-5 BF). Kualitas hubungan manajer tersebut dengan bawahannya diukur dengan Leader Member Exchange-Multidimensional Measure (LMX-MDM) yang diisi oleh para staf. Hasil uji hipotesis menunjukkan bahwa trait dari domain negative affectivity, detachment, antagonism, dan psychoticism memiliki hubungan signifikan dengan LMX. Hubungan yang ditemukan bersifat negatif, sejalan dengan temuan menggunakan domain-domain trait non maladaptif pada five-factor model yang ekuivalen dengan domain-domain PID-5 BF.

ABSTRACT Individuals with maladaptive personality traits that fall below the threshold for personality disorders can still function and even succeed in daily life. In a work environment, leaders with maladaptive personality traits have a potential to develop interpersonal relationship problems with their 
subordinates. This research was aimed to investigate the relationship between maladaptive personality traits and the leader-subordinate relationship using the leader-member exchange (LMX) approach. Participants of this research were 72 dyads of first line managers and their subordinates in company $X$. A manager may have more than one subordinates, resulting in a lower number of managers in the sample with only 21 participants. Maladaptive personality traits in the managers was measured using the Personality Inventory for DSM-5 Brief Form (PID-5 $\mathrm{BF})$. The quality of the relationship between the managers and their subordinates was measured using the Leader Member ExchangeMultidimensional Measure (LMX-MDM) questionnaire which are filled by non-managerial staff. The results of the study indicated that traits of four domains: negative affectivity, detachment, antagonism, and psychoticism show a significant relationship with LMX. The relationships found are in accordance with previous findings using non maladaptive traits in the fivefactor model that are equivalent with the domains of PID-5 BF.

\section{PENDAHULUAN}

Diagnosis gangguan kepribadian dibuat menggunakan kategorisasi yang tercantum dalam Diagnostic and Statistical Manual for Mental Disorder edisi kelima (DSM-5). Meski demikian, pendekatan kategorikal dalam diagnostik sudah mendapat kritik sejak DSM-III, DSM-III-R, and DSM-IV (Zimmerman, 2012). Batasanbatasan (threshold) yang dicantumkan dianggap meragukan karena tanpa landasan yang jelas. Schmeck, Schlüter-Müller, Foelsch, dan Doering (2013) menyampaikan bahwa diagnosis bisa diberikan pada individu tanpa gangguan (false positive) dan terdapat pula individu dengan gangguan yang tidak tedeteksi (false negative), terutama pada gangguan kepribadian. Babiak, Neumann, dan Hare (2010) menemukan bahwa individu dengan trait gangguan kepribadian dapat ditemukan di perusahaan-perusahaan, bahkan dapat mencapai jabatan yang cukup tinggi.

Fenomena demikian lebih mudah dipahami jika kita tidak lagi melihat gangguan kepribadian sebagai sebuah kategorisasi, melainkan adanya trait kepribadian maladaptif dalam diri seseorang. Trait kepribadian maladaptif yang tidak terdeteksi dapat menimbulkan dampak yang signifikan dalam interaksi di tempat kerja (Le, Donnellan, \& Conger, 2013). Dampak trait kepribadian maladaptif akan semakin besar jika terdapat dalam diri pemimpin dalam sebuah organisasi.

Trait kepribadian seseorang dapat berkontribusi dalam perjalanan kariernya menjadi pemimpin, termasuk trait yang maladaptif. Judge dan Robbins (2017) menjelaskan bagaimana trait kepribadian mampu memprediksi kesuksesan karir seseorang. Conscientiousness paling dapat memprediksi kinerja dan keberhasilan di organisasi secara umum. Extraversion dan agreeableness dapat membantu seseorang dalam berinteraksi dengan orang lain, termasuk kemunculan seseorang sebagai pemimpin di kelompoknya. Openness to experience dapat memprediksi efektivitas kepemimpinan seseorang. Neuroticism dapat memprediksi kepuasan kerja dan kepuasan hidup seseorang.

Trait kepribadian maladaptif pemimpin menjadi penting untuk diperhatikan karena akan sangat menentukan interaksinya dengan bawahan. Pemimpin dengan kepribadian maladaptif berpotensi menggunakan metode coping yang tidak sehat di tempat kerja dan yang berujung pada masalah dalam hubungan 
interpersonal dengan rekan kerja. Manusia memiliki kecenderungan memproyeksikan perasaan, keinginan, dan pemikiran negatifnya ke orang lain, tetapi individu dengan gejala gangguan kepribadian melakukannya secara lebih intens (Ettner, Maclean, \& French, 2011). Coping yang tidak sehat dapat berujung pada pengambilan keputusan yang tidak tepat, timbulnya suasana kerja yang tidak nyaman bagi rekan kerja, hilangnya kepercayaan dari rekan kerja, dan tindakan-tindakan tidak etis lainnya (Ouimet, 2010). Hengartner, Müller, Rodgers, Rössler, dan Ajdacic-Gross (2013) juga menunjukkan bahwa kepribadian yang maladaptif berasosiasi dengan konflik di tempat kerja, terutama pada individu dengan kecenderungan gangguan kepribadian cluster A dan B di DSM-5.

Board dan Fritzon (2005) menunjukkan bahwa karakteristik gangguan kepribadian ditemukan di sampel manajer senior. Bahkan saat dibandingkan dengan sampel pasien psikiatrik, sampel manajer menunjukkan kecenderungan yang setara untuk gangguan kepribadian narcissistic dan obsessive-compulsive, dan kecenderungan lebih kuat untuk gangguan kepribadian histrionic. Lebih lanjut, Board dan Fritzon (2005) juga mendeskripsikan partisipan dengan indikasi gangguan kepribadian histrionic cenderung akan memperlihatkan sifat tidak tulus, memikirkan dirinya sendiri, dan memanipulasi orang lain demi mendapatkan keinginannya. Sedangkan partisipan dengan indikasi gangguan kepribadian narcissistic seringkali diwarnai dengan delusi untuk mengagungkan diri sendiri, tidak memiliki empati terhadap rekan kerjanya, dan perilaku mengeksploitasi orang lain. Partisipan dengan indikasi gangguan kerpibadian obsessive-compulsive cenderung memiliki perfeksionisme yang tinggi, terlalu membaktikan diri untuk pekerjaan, keras kepala, dan dapat memunculkan sikap otoriter.
Gangguan kepribadian pada pemimpin organisasi juga sudah diteliti dari sudut pandang manajemen. Webster, Brough, dan Daly (2016) menggunakan konsep toxic leadership untuk menggambarkan perilaku yang kasar (abusive) dan destruktif dari pemimpin di tempat kerja. Toxic leadership dapat muncul dalam bentuk perilaku atasan yang memanipulasi bawahannya, bullying, mengintimidasi, kasar, tidak bisa mengendalikan emosi, perilaku narsistik, perilaku micromanaging, dan perilaku pasif-agresif. Perilaku-perilaku demikian dijelaskan dengan adanya karakteristik kepribadian yang maladaptif.

Perlaku-perilaku tersebut menimbulkan dampak psikologis, emosional, dan fisik pada karyawan yang mengalaminya (Webster, Brough, \& Daly, 2016). Penelitian ini juga menunjukan bahwa coping yang paling sering digunakan oleh para karyawan pada akhirnya adalah menghindari atasan, dengan mengambil cuti atau leave, meminta dipindahkan ke unit lain, sampai mengundurkan diri dari perusahaan karena merasa tidak memiliki kendali dalam masalah ini.

Kepribadian yang maladaptif juga merupakan hal yang sulit dan membutuhkan waktu yang lama untuk diperbaiki. Menurut Bateman, Gunderson, dan Mulder (2015), individu dengan kepribadian maladaptif sulit diubah karena kepribadian sudah terbentuk dan konsisten pada usia dewasa, terutama pada cara berpikir dan berperasaan. Salah satu faktor penghambatnya adalah, individu dengan kepribadian yang maladaptif sulit menyadari permasalahan dalam dirinya dan seringkali cenderung menyalahkan lingkungannya. Hal ini juga yang menyebabkan pasien-pasien gangguan kepribadian jarang mencari bantuan profesional atau menyelesaikan seluruh sesi terapi (American Psychiatric Association, 2013). Oleh karena itu dibutuhkan pemahaman lebih mendalam terhadap permasalahan ini agar solusinya dapat dicari. 
Dalam konteks organisasi, gambaran mengenai kepribadian anggotanya biasanya hanya diperoleh lewat psikotes saat rekrutmen. Namun, alat-alat ukur demikian biasanya hanya digunakan untuk mengetahui kecocokan seseorang dengan organisasi dan pekerjaannya saja. Selain itu, alat-alat ukur tersebut kurang dapat menunjukkan aspek maladaptif dari kepribadian individu. Padahal, traits kepribadian maladaptif pada individu sulit disadari pada saat asesmen kerja karena baru terlihat saat individu tidak mengendalikan perilakunya (Kaiser, LeBreton, \& Hogan, 2013). Sebagai contoh, saat wawancara kerja individu dengan ciri narcissistic seringkali terlihat memiliki kualitas seorang pemimpin karena terlihat positif dan percaya diri. Padahal dalam jangka panjang pemimpin yang demikian bisa berdampak destruktif pada dinamika kelompok (Schilling \& Schyns, 2014).

Untuk mendiagnosis traits kepribadian maladaptif, DSM-5 sudah memberikan klasifikasi trait-trait tersebut dalam sebuah model hybrid untuk diagnosis gangguan kepribadian. Klasifikasi tersebut didasarkan pada five-factor model (FFM) dari Costa dan McCrae (Anderson dkk., 2013). Di dalamnya terdapat lima domain trait yang ekuivalen dengan FFM tetapi dari sudut pandang patologi, yaitu negative affectivity, detachment, psychoticism, antagonism, dan disinhibition (American Psychiatric Association, 2013). Krueger, Derringer, Markon, Watson, dan Skodol (2013) sudah mengembangkan instrumen untuk mengukur traits kepribadian maladaptif, yaitu Personality Inventory for DSM-5 (PID-5). Anderson dkk. (2013) sudah menemukan bahwa domain-domain dari PID-5 berkorelasi erat dengan instrumen lain yang sejenis, yaitu skala PSY-5 dari Minnesota Multiphasic Personality-2 Restructured Form (MMPI2-RF).

Penggunaan PID-5 tidak terbatas pada sisi patologis kepribadian, dan tetap dapat menangkap sisi lain dari trait kepribadian maladaptif yang sifatnya adaptif (Krueger \& Markon, 2014). Thomas dkk. (2012) juga menyatakan bahwa domain-domain dari PID-5 juga masih berkorelasi dengan domain yang ekuivalen dari FFM Rating Form (FFMRF). Dengan demikian, PID-5 dapat digunakan dalam asesmen trait kepribadian maladaptif pada individu-individu yang belum dapat didiagnosis dengan gangguan kepribadian.

Selain kurang fokus pada potensi maladaptif kepribadian, penelitianpenelitian mengenai kepribadian pemimpin di organisasi juga cenderung menggunakan sudut pandang pemimpin. Padahal dampak dari trait kepribadian maladaptif pemimpin adalah pada kualitas relasi vertikal antara atasan dan bawahan. Oleh karena itu kerangka pikir yang dapat memberikan sudut pandang bawahan menjadi penting untuk digunakan. Relasi antara pemimpin dan bawahan di organisasi biasanya dibahas dengan konsep leader-member exchange atau LMX (Bernerth, Walker, \& Harris, 2015).

Karakteristik inti LMX adalah pertukaran timbal balik antara anggotaanggota dalam diad pemimpin dan bawahan (Bernerth, Walker \& Harris, 2015). Karena kualitas LMX ditentukan baik oleh pemimpin maupun bawahan, maka relasi antara pemimpin dan bawahan-bawahannya bisa berbeda satu sama lain. Kualitas LMX yang baik memiliki dampak positif bagi pemimpin, bawahan, maupun organisasi secara keseluruhan. Bagi bawahan, kontribusi yang bisa diperoleh dari pemimpin berbentuk informasi dan dukungan. Bagi pemimpin dan organisasi, karyawan akan menanggapi LMX yang baik dengan menunjukkan sikap dan perilaku kerja yang baik pula. Bagi kedua pihak, kenyamanan dalam relasi sangat ditentukan oleh kualitas timbal balik dan kesetaraan (Epitropaki \& Martin, 2015).

Sebaliknya, LMX yang tidak harmonis dapat menimbulkan perasaan negatif yang berujung pada perilaku yang tidak produktif. LMX telah ditemukan sebagai variabel yang memoderasi supervisi yang kasar (abusive) dengan kepuasan dan 
organizational deviance pada bawahan (Lian, Lance-Ferris, \& Brown, 2012).

Walaupun LMX bersifat diadik, tetapi sejumlah penelitian sudah menemukan relasi yang signifikan antara LMX dengan beberapa trait kepribadian pemimpin (Bernerth, Armenakis, Field, Giles, \& Jack Walker, 2007; Joo \& Ready, 2012; Sears \& Hackett, 2011; Schyns, Maslyn, \& Van Veldhoven, 2012). Artinya faktor internal dalam pihak pemimpin dapat berdampak terhadap LMX antara kedua pihak, pemimpin dan bawahan.

Penelitian ini bertujuan untuk melihat hubungan trait kepribadian maladaptif seorang pimpinan di tempat kerja dengan relasi interpersonal antara pimpinan tersebut dengan bawahannya atau disebut sebagai LMX. Karena trait kepribadian maladaptif diklasifikasikan ke dalam domain-domain trait yang relatif independen, maka hipotesis dalam penelitian ini dirumuskan antara domain trait dengan kualitas LMX. Hipotesis pertama penelitian ini adalah terdapat hubungan antara domain negative affectivity dengan LMX. Hipotesis kedua dalam penelitian ini adalah terdapat hubungan antara domain detachment dengan LMX. Hipotesis ketiga dalam penelitian ini adalah terdapat hubungan antara domain antagonism dengan LMX. Hipotesis keempat dalam penelitian ini adalah terdapat hubungan antara domain disinhibition dengan LMX. Hipotesis kelima dalam penelitian ini adalah terdapat hubungan antara domain psychoticism dengan LMX.

\section{METODE PENELITIAN Partisipan}

Partisipan penelitian ini terdiri atas 21 karyawan dengan posisi setara manajer tingkat first line dan 72 karyawan staf nonmanajerial. Karena pengukuran LMX bersifat diadik maka seluruh karyawan staf non-manajerial dalam sampel penelitian ini merupakan bawahan dari para manajer dalam sampel yang sama. Satu orang manajer bisa memiliki sejumlah bawahan sehingga jumlah sampel manajer lebih sedikit dari sampel karyawan nonmanajerial. Artinya, secara keseluruhan terdapat 72 diad manajer dan staf dalam penelitian ini. Sampel berasal dari karyawan salah satu perusahaan multinasional di Jakarta.

Partisipan penelitian memiliki ratarata usia 34,25 tahun dengan rincian 40,25 tahun untuk responden manajer dan 32,58 tahun untuk staf. Dari 21 orang manajer, 14 adalah laki-laki $(66,67 \%)$ dan tujuh adalah perempuan $(33,33 \%)$. Dari 72 orang staf, 38 adalah perempuan $(52,78 \%)$ dan 34 adalah laki-laki $(47,22 \%)$.

\section{Instrumen}

Traits kepribadian maladaptif pada manajer diukur dari kuesioner PID-5 -Brief Form (PID-5 BF) yang dikembangkan oleh Krueger dkk. (2013). PID-5 BF merupakan bentuk singkat dari PID-5 yang terdiri atas 25 soal. Soal-soal dalam PID-5 BF seluruhnya berasal dari PID-5. Sama seperti PID-5, PID-5 BF memiliki 5 domain trait, yaitu negative affectivity, detachment, disinhibition, antagonism, dan psychoticism. Setiap soal berbentuk skala dengan empat pilihan jawaban dari "sangat tidak sesuai atau seringkali tidak sesuai" hingga "sangat sesuai atau seringkali sesuai". Pilihan jawaban tersebut akan menghasilkan skor dari 0 sampai dengan 3 .

PID-5 BF yang digunakan dalam penelitian ini menggunakan soal-soal dari PID-5 yang sudah diadaptasi ke dalam Bahasa Indonesia oleh Adhiatma, Pinaima, Siregar, Nova, dan Kencana (2014). Untuk memastikan bahwa soal-soal di PID-5 BF tetap dapat mengukur trait kepribadian maladaptif seperti PID-5, peneliti melakukan uji validitas dan reliabilitas dari PID-5 BF. Uji psikometrik dilakukan dengan kriteria partisipan dapat berbahasa Indonesia dan sudah mencapai usia minimal untuk mengisi PID-5 BF, yaitu 18 tahun (Krueger dkk., 2013). Sampel tersebut terdiri atas 118 partisipan yang terdiri atas 44 laki-laki dan 74 perempuan dengan ratarata usia 21,39 tahun. Reliabilitas 
diperhitungkan dengan rumus cronbach alpha untuk setiap domain trait dengan hasil bervariasi antara 0,54 sampai dengan 0,85 . Koefisien cronbach alpha untuk setiap domain dapat dilihat di tabel 1 . Corrected item-total correlation dihitung antara setiap soal dengan skor total domain trait masing-masing soal. Koefisien korelasi yang diperoleh berkisar antara 0,20 - 0,79. Untuk lebih spesifik, kisaran koefisien korelasi pada domain negative affectivity adalah antara 0,20 sampai dengan 0,37; domain detachment antara 0.50 sampai dengan 0,79; domain antagonism antara 0,40 sampai dengan 0,73; domain disinhibition antara 0,3 sampai dengan 0,48; domain psychoticism antara 0,48 sampai dengan 0,61 .

Leader-member exchange diukur dengan LMX-MDM yang dikembangkan oleh Liden dan Maslyn (1998). LMX-MDM terdiri atas 12 soal yang mengukur empat dimensi, yaitu professional respect, loyalty, affect, dan contribution. Setiap soal memiliki respon berbentuk skala dengan tujuh pilihan jawaban dari "sangat tidak setuju" sampai dengan "sangat setuju". Skor yang dihasilkan adalah dari 1 sampai dengan 7 . Kuesioner yang digunakan dalam penelitian ini adalah hasil terjemahan yang dilakukan peneliti dengan backward dan forward translation. Dua orang penerjemah dengan kriteria menyandang gelar Sarjana Psikologi dan fasih berbahasa Inggris menerjemahkan LMX-MDM secara independen ke Bahasa Indonesia. Terjemahan dari kedua penerjemah digabungkan menjadi satu form yang diterjemahkan kembali ke dalam Bahasa Inggris oleh satu orang penerjemah lain dengan kriteria yang sama seperti sebelumnya. Hasil penerjemahan kembali ke Bahasa Inggris kemudian dibandingkan dengan soal asli dalam Bahasa Inggris untuk menentukan apakah terjemahan ke Bahasa Indonesia perlu direvisi lagi atau tidak.

Uji validitas dan reliabilitas LMXMDM dilakukan dengan kriteria responden berusia di atas 20 tahun, bekerja sebagai karyawan di sebuah perusahaan, dan memiliki satu orang supervisor. Jumlah responden pada uji konsistensi internal dan reliabilitas adalah 68 individu dengan ratarata usia 23,07 tahun. Perhitungan reliabilitas dengan cronbach alpha menghasilkan koefisien sebesar 0,93. Cronbach alpha untuk setiap domain LMX dapat dilihat di tabel 1.

Perhitungan corrected item-total correlation menghasilkan koefisien korelasi antara 0,68 sampai dengan 0,83. Kisaran koefisien korelasi pada domain professional respect adalah antara 0,68 sampai dengan 0,72 ; domain loyalty antara 0,43 sampai dengan 0,71 ; domain contribution antara 0,79 sampai dengan 0,83 ; domain affect antara 0,77 sampai dengan 0,81 .

Tabel 1

Cronbach Alpha Domain PID-5 BF dan LMX-MDM

\begin{tabular}{llll}
\hline Domain PID-5 BF & $\begin{array}{l}\text { Cronbach } \\
\text { alpha }\end{array}$ & Domain LMX-MDM & $\begin{array}{l}\text { Cronbach } \\
\text { alpha }\end{array}$ \\
\hline Negative affectivity & 0,539 & Professional respect & 0,842 \\
Detachment & 0,848 & Loyalty & 0,773 \\
Antagonism & 0,743 & Contribution & 0,902 \\
Disinhibition & 0,661 & Affect & 0,887 \\
Psychoticism & 0,764 & & \\
\hline
\end{tabular}

Teknik Analisis Data

Analisis data penelitian ini akan dilakukan dengan menghitung korelasi spearman-brown antara skor total masingmasing domain trait PID-5 $\mathrm{BF}$ (negative affectivity, disinhibition, detachment, 
antagonism, dan psychoticism) dengan skor total LMX-MDM. Korelasi spearmanbrown digunakan karena distribusi data yang tidak normal berdasarkan tes shapirowilk.

Korelasi diperhitungkan dalam setiap diad. Artinya skor total LMX-MDM yang diisi oleh staf dipasangkan dengan total skor domain PID-5 BF yang diisi oleh manajer yang membentuk hubungan diadik antara satu orang atasan dengan satu orang bawahannya (Sears \& Hackett, 2011; Schyns, Maslyn, \& van Veldhoven, 2012; Zhang, Wang, \& Shi, 2012).

\section{Prosedur Penelitian}

Pengambilan data dilakukan pada tanggal tanggal 11- 26 Juni 2018. Pengambilan data dilakukan setelah mendapat persetujuan dari manajer HR PT $X$. Persetujuan diberikan setelah manajer HR PT X mendapat penjelasan menenai tujuan penelitian ini berikut proposal penelitian. PT X adalah sebuah perusahaan multinasional di Indonesia yang bergerak di bidang farmasi. Peneliti hanya mendapat izin melakukan pengambilan data pada karyawan di kantor pusat PT X. Pengambilan data terhadap manajer tingkat first line dilakukan menggunakan instrumen versi cetak yang disertai lembar informed consent. Sementara staf non manajerial dari masing-masing manajer mengisi informed consent dan LMX-MDM secara daring.

Partisipan manajer first line dimintai kesediaannya dengan pendekatan secara individual. Sementara pendekatan terhadap karyawan non manajerial dilakukan dengan mengirimkan surel berisi penjelasan mengenai penelitian dan tautan untuk mengisi data. Calon partisipan yang memenuhi kriteria diperoleh dengan mengakses data demografis karyawan di kantor pusat PT X. Data dari setiap partisipan diberi kode unik untuk menghindari tercampurnya data.

Tabel 2

Skor Deskriptif Variabel Penelitian

\begin{tabular}{lcc}
\hline Variabel & M & SD \\
\hline PID-5 BF & & \\
Negative affectivity & 0,9 & 0,82 \\
Detachment & 0,6 & 0,98 \\
Antagonism & 0,6 & 0,92 \\
Disinhibition & 0,48 & 1,02 \\
Psychoticism & 0,45 & 0,68 \\
LMX-MDM & & \\
Leader-member exchange & 5,34 & 1,25 \\
\hline
\end{tabular}

\section{ANALISIS DAN HASIL}

Rata-rata skor PID-5 BF dan LMXMDM dapat dilihat di tabel 2. Secara umum para manajer menunjukkan skor yang rendah pada lima domain trait di PID-5 BF. Respon para manajer berkisar antara pilihan "agak atau kadang-kadang tidak sesuai" atau "sangat atau sering tidak sesuai". Skor ini memberikan kesan bahwa karakteristik trait kepribadian maladaptif tidak menonjol di sampel ini. Di sisi lain, para staf menunjukkan skor rata-rata yang tinggi, yang berarti jawaban lebih mendekati pilihan "agak setuju". Namun perlu diperhatikan bahwa persebaran data respon dari kuesioner LMX-MDM juga cukup besar, sebesar 1,25 poin dari rata-rata. 
Tabel 3

Hasil Uji Hipotesis

\begin{tabular}{ll}
\hline Variabel & $\begin{array}{l}\text { LMX-MDM } \\
(\mathrm{N}=72)\end{array}$ \\
\hline Negative affectivity & $-0,309 * *$ \\
Detachment & $-0,265^{*}$ \\
Antagonism & $-0,339 *$ \\
Disinhibition & $-0,007$ \\
Psychoticism & $-0,310 * *$ \\
\hline **Korelasi signifikan pada alpha level 0,01 \\
$*$ Korelasi signtifikan pada alpha level 0,05
\end{tabular}

Pengujian hipotesis menghasilkan hubungan yang signifikan pada empat dari lima hipotesis yang diuji. Hasil uji hipotesis secara rinci dapat dilihat pada tabel 3 . Berdasarkan hasil uji hipotesis tersebut dapat dinyatakan bahwa dalam penelitian ini:

1. Hipotesis pertama diterima, yang berarti ada korelasi yang signifikan antara domain negative affectivity manajer dengan leader-member exchange.

2. Hipotesis kedua diterima, yang berarti ada korelasi yang signifikan antara domain detachment manajer dengan leader-member exchange.

3. Hipotesis ketiga diterima, yang berarti ada korelasi yang signifikan antara domain antagonism manajer dengan leader-member exchange.
4. Hipotesis keempat ditolak, yang berarti tidak ada korelasi yang signifikan antara domain disinhibition manajer dengan leader-member exchange.

5. Hipotesis kelima diterima, yang berarti ada korelasi yang signifikan antara domain psychoticism manajer dengan leader-member exchange.

Lebih lanjut, korelasi antara dimensidimensi LMX-MDM dengan domaindomain PID-5 BF diperhitungkan sebagai analisis tambahan. Analisis ini diharapkan dapat memberikan informasi tambahan dalam memahami hasil uji hipotesis, dengan melihat kontribusi masing-masing dimensi LMX dalam relasinya dengan dimensi-dimensi traits kepribadian maladaptif.

Tabel 4

Korelasi Sperman-Brown antara Domain-Domain PID-5 BF dan Dimensi-Dimensi $L M X-M D M$

\begin{tabular}{lllll}
\hline & $\begin{array}{l}\text { Professional } \\
\text { respect }\end{array}$ & Loyalty & Affect & Contribution \\
\hline $\begin{array}{l}\text { Negative } \\
\text { affectivity }\end{array}$ & $-0,288^{* *}$ & $-0,272^{*}$ & $-0,369 * *$ & $-0,184$ \\
Detachment & $-0,218^{*}$ & $-0,361 * *$ & $-0,283^{* * *}$ & 0,000 \\
Antagonism & $-0,252^{*}$ & $-0,278^{* *}$ & $-0,388^{* *}$ & $-0,185$ \\
Disinhibition & $-0,096$ & $-0,075$ & $-0,051$ & 0,042 \\
Psychoticism & $-0,275^{* *}$ & $-0,081$ & $-0,401 * *$ & $-0,343 * *$ \\
\hline \multicolumn{5}{r}{ Korelasi signifikan pada alpha level 0,01} \\
\\
\end{tabular}


Dimensi professional respect dan affect menunjukkan hasil yang sama, berkorelasi signifikan dengan trait negative affectivity, detachment, psychoticism dan antagonism. Dimensi loyalty berkorelasi signifikan dengan trait negative affectivity, antagonism, dan detachment. Dimensi contribution adalah yang paling sedikit menunjukkan korelasi dengan domaindomain trait, yaitu hanya dengan trait psychoticism. Patut diperhatikan bahwa semua korelasi yang signifikan bersifat negatif.

\section{DISKUSI}

Hasil uji hipotesis menunjukkan adanya hubungan antara trait kepribadian maladaptif dari domain negative affectivity, detachment, antagonism, dan psychoticism dengan LMX. Domain disinhibition adalah satu-satunya domain yang tidak menunjukkan adanya hubungan dengan LMX. Temuan ini secara umum mendukung ide bahwa karakteristik kepribadian pemimpin yang tidak sehat dapat berkontribusi terhadap hubungan yang terbentuk dengan bawahannya. Selain itu, arah dari hubungan per domain juga mengindikasikan kaitan antara variasi dalam setiap trait kepribadian dengan hubungan pemimpin dan bawahannya.

Domain negative affectivity merupakan domain yang berbanding lurus dengan domain neuroticism pada FFM. Penelitian terdahulu menunjukkan bahwa tingkat neuroticism yang tinggi dapat berdampak negatif terhadap kepemimpinan (Deinert, Homan, Boer, Voelpel, \& Gutermann, 2015). Beberapa hal yang dapat menjelaskan hal tersebut adalah pemimpin dengan tingkat neuroticism yang tinggi lebih mungkin menghindari tanggungjawab kepemimpinan, kurang terlibat dengan bawahan, serta sulit dipandang sebagai teladan.

Bernerth dkk. (2007) juga sudah menunjukkan adanya korelasi negatif antara neuroticism dengan LMX. Dengan demikian korelasi negatif antara domain negative affectivity dan LMX pada penelitian ini mendukung temuan sebelumnya. Ekspresi emosi negatif yang kuat pada pemimpin saat berinteraksi dengan bawahannya meningkatkan kemungkinan terbentuknya kualitas hubungan kurang baik dengan bawahannya tersebut

Domain detachment merupakan domain yang berbanding terbalik dengan domain extraversion pada FFM. Sedangkan extraversion sudah ditemukan sebagai domain yang berkontribusi secara positif terhadap LMX. Korelasi positif ditemukan antara extraversion dengan LMX dalam penelitian Bernerth dkk. (2007). Schyns, Maslyn, dan van Weldhoven (2012) juga menemukan bahwa pemimpin dengan tingkat extraversion yang tinggi dapat membangun dan memelihara LMX, bahkan di kelompok yang besar. Karena detachment berbanding terbalik dengan extraversion, maka korelasi negatif antara domain detachment dan LMX di penelitian ini sejalan dengan temuan-temuan sebelumnya tersebut. Pemimpin yang tidak banyak berinteraksi dengan bawahannya cenderung memiliki kualitas hubungan yang tidak optimal dengan bawahannya.

Sama seperti detachment, domain antagonism juga berbanding terbalik dengan padanannya di FFM, yaitu domain agreeableness. Korelasi negatif antara domain antagonism dengan LMX di penelitian ini sejalan dengan penelitian sebelumnya yang menemukan hubungan positif antara agreeableness dengan LMX (Bernerth dkk., 2007). Lebih spesifik lagi, penelitian lain melaporkan bahwa agreeableness pemimpin lebih menentukan LMX dari persepsi bawahan dan sebaliknya (Yoon \& Bono, 2016). Dalam penelitian ini LMX diukur dari persepsi bawahan sehingga sesuai dengan hubungan yang signifikan dengan agreeableness pemimpin. Sebaliknya, dapat dipahami bahwa sikap dan perilaku kurang positif dari pemimpin berpotensi menimbulkan hubungan yang kurang baik dengan bawahannya. 
Berbeda dengan domain lain di PID-5 $\mathrm{BF}$, hubungan antara domain psychoticism dengan domain openness to experience dalam FFM masih inkonsisten. Kesan yang sama juga terlihat dalam hasil penelitian ini. Penelitian ini menemukan korelasi yang signifikan antara domain psychoticism dengan LMX, sementara penelitian sebelumnya tidak menemukan hubungan antara openness to experience dengan LMX (Bernerth dkk., 2007). Meski demikian, jika mengingat bahwa domain psychoticism berisi ciri-ciri kepribadian yang tidak sehat, dapat dipahami bahwa skor yang tinggi juga berkontribusi secara negatif pada kualitas hubungan antara pemimpin dan bawahan. Temuan ini juga mendukung temuan sebelumnya yang belum dapat menyimpulkan bahwa psychoticism merupakan padanan dari openness to experience.

Domain disinhibition adalah satusatunya domain yang tidak menunjukkan adanya korelasi dengan LMX di penelitian ini. Secara konseptual domain disinhibition seharusnya berbanding terbalik dengan domain conscientiousness di FFM. Conscientiousness merupakan domain yang diketahui berdampak positif terhadap kinerja pemimpin. Bernerth dkk. (2007) menemukan bahwa pemimpin dengan tingkat conscientiousness yang tinggi akan membuat pemimpin lebih terdorong untuk membantu bawahannya agar dapat mencapai hasil kerja yang baik. Penelitian tersebut juga menemukan korelasi positif antara conscientiousness dengan LMX. Temuan yang sama juga diperoleh di kelompok besar, khususnya pada dimensi loyalty (Schyns, Maslyn, \& van Weldhoven, 2012). Namun korelasi yang ditemukan bersifat lemah sehingga dapat dipahami jika penelitian ini tidak menunjukkan hasil yang sejalan. Mengingat conscientiousness lebih banyak berdampak positif terhadap LMX melalui peningkatan kinerja, maka disinhibition dapat diduga lebih berdampak terhadap penurunan kinerja dan bukan terhadap kualitas relasi pemimpin dan bawahan. Disinhibition yang dipandang sebagai karakteristik yang kurang positif pada pemimpin ternyata belum tentu berdampak pada relasi dengan bawahannya.

Untuk memahami lebih jauh tentang keterkaitan antara domain-domain trait kepribadian maladaptif dengan LMX, maka korelasi dengan dimensi-dimensi LMX perlu dianalisis pula. Dari lima domain dalam PID-5 BF, empat domain memiliki korelasi dengan tiga dimensi dalam LMX. Hanya domain disinhibition yang tidak menunjukkan korelasi dengan dimensi apapun di dalam LMX. Mengingat domain tersebut memang tidak menunjukkan korelasi yang signifikan dengan LMX secara keseluruhan maka dapat dikatakan bahwa hasil penelitian ini mengindikasikan bahwa domain disinhibition tidak memberi dampak terhadap hubungan pemimpin dan bawahan dari segi apapun.

Tiga domain lain di PID-5 BF, yaitu negative affectivity, detachment, dan antagonism menunjukkan pola korelasi yang sama dengan dimensi-dimensi LMX. Ketiga domain tersebut berkorelasi secara signifikan dengan dimensi LMX professional respect, loyalty, dan affect, tetapi tidak berkorelasi dengan dimensi contribution. Pola ini mengindikasikan bahwa trait kepribadian maladaptif lebih mungkin berkontribusi negatif pada aspek sikap atau emosional dari relasi pemimpin dan bawahan, tetapi tidak terlalu berdampak pada aspek yang lebih ditentukan perilaku nyata seperti contribution. Di konteks tempat kerja, hal ini dapat dipahami karena kontribusi seorang pemimpin terhadap bawahan dan sebaliknya seharusnya lebih ditentukan oleh aspek organisasi di perusahaan seperti deskripsi tugas, struktur organisasi, budaya organisasi, dan lain-lain.

Domain psychoticism menunjukkan pola yang berbeda yaitu berkorelasi dengan semua dimensi LMX kecuali loyalty. Hal ini menimbulkan kesan bahwa pemimpin dengan sikap dan perilaku yang tidak umum tidak selalu menimbulkan persepsi negatif terhadap caranya mendukung bawahan, walaupun kedekatan secara personal 
(professional respect, affect) belum tentu dirasakan. Pola lain yang menarik adalah dimensi affect yang berkorelasi dengan semua domain PID-5 BF kecuali disinhibition yang memang tidak berkorelasi dengan LMX sama sekali. Temuan ini mendukung dugaan bahwa dampak dari traits kepribadian yang maladaptif dapat menimbulkan permasalahan pada hubungan interpersonal antara individu terlepas dari konteks apapun (Krueger \& Markon, 2014).

Secara umum, skor deskriptif partisipan pada kedua alat ukur juga menarik. Respon pada PID-5 BF cenderung berkisar pada skor nol hingga satu. Artinya partisipan cenderung memberi jawaban yang mengarah pada kutub yang lebih adaptif dari domain-domain PID-5 BF, bukan kutub yang lebih maladaptif. Dua hal dapat berperan menghasilkan temuan tersebut. Pertama, partisipan penelitian berasal dari populasi non-patologis sehingga memang tidak menunjukkan karakteristik kepribadian yang tidak sehat. Kedua, terdapat risiko bias social desirability pada alat ukur yang digunakan. Proses asesmen dalam penelitian trait kepribadian yang berkonotasi negatif biasanya lebih kompleks karena tingginya bias social desirability pada responden (Schilling \& Schyns, 2014). Di sisi lain, skor LMX-MDM cenderung berkisar pada skor yang tinggi. Karena LMX-MDM diisi oleh bawahan, hal ini juga menimbulkan dugaan ke arah adanya peranan isu social desirability.

Sejumlah keterbatasan lain penelitian ini juga perlu diperhatikan. Dari segi partisipan, penelitian ini masih terbatas pada satu perusahaan dan satu tingkat kepemimpinan saja (manajer first line). Dengan demikian interaksi aspek kepribadian dengan karakteristik organisasi belum terlalu tergambar. Selain itu, variabel yang belum dikontrol dalam penelitian ini adalah lamanya atasan dan bawahan bekerja bersama. Zhang, Wang, dan Shi (2012) meyebutkan lamanya hubungan antara atasan dan bawahan sebagai salah satu variabel yang dapat berperan. Kekuatan korelasi yang ditemukan dalam penelitian ini tidak terlalu besar sehingga kontribusi faktor-faktor lain tersebut terhadap LMX juga tidak dapat diabaikan.

\section{SIMPULAN}

Hasil pengujian hipotesis menunjukkan adanya hubungan antara sejumlah trait kepribadian maladaptif dengan LMX, yaitu pada domain negative affectivity, detachment, antagonism, dan psychoticism. Arah hubungan yang ditemukan seluruhnya negatif. Hasil ini mendukung ide bahwa adanya karakteristik kepribadian yang tidak sehat pada diri pemimpin berpotensi untuk menimbulkan dampak negatif pada hubungan yang terbangun dengan bawahannya. Meski demikian, hubungan yang ditemukan tidak terlalu kuat sehingga kontribusi dari faktorfaktor lain terhadap hubungan atasan dan bawahan juga perlu diperhatikan.

\section{SARAN}

Hasil penelitian ini dapat memberi gambaran awal mengenai mengenai keterkaitan antara kepribadian pemimpin dengan hubungan antara pemimpin dan bawahan. Namun penelitian lebih lanjut masih dibutuhkan pada organisasi, pemimpin, dan bawahan yang lebih bervariasi. Dengan demikian hasil yang ditemukan lebih dapat digeneralisasikan ke konteks yang lebih luas. Secara khusus, penelitian pada sampel pemimpin dengan karakteristik kepribadian yang maladaptif akan memberi gambaran yang kontras dengan sampel penelitian ini.

Selain itu, kontrol lebih kuat perlu dilakukan untuk mengatasi keterbatasan dari alat ukur. Secara khusus, pemilihan soal-soal dalam PID-5 BF dari PID-5 versi lengkap dapat diteliti lebih lanjut. Fossati dkk. (2015) menyebutkan bahwa soal-soal dalam PID-5 BF versi bahasa Inggris belum tentu tepat digunakan dalam konteks bahasa lain. Oleh sebab itu Fossati dkk. (2015) menyarankan untuk memilih item-item yang memiliki komponen psikometrik yang 
paling baik untuk dijadikan perwakilan item dan setiap domain trait.

\section{DAFTAR PUSTAKA}

Adhiatma, W., Pinaima, R., Siregar, L.B., Nova, P., \& Kencana, K. (2014).

Exploratory factor analysis for Indonesian version of PID-5. Anima, Indonesian Psychological Journal, 29 (4), 199-206.

American Psychiatric Association. (2013). Diagnostic and statistical manual of mental disorders $\left(5^{\text {th }}\right.$ ed.). Author. https://doi.org/10.1176/appi.books.97 80890425596.

Anderson, J. L., Sellbom, M., Bagby, R. M., Quilty, L. C., Veltri, C. O., Markon, K. E., \& Krueger, R. F. (2013). On the convergence between PSY-5 domains and PID-5 domains and facets: Implications for assessment of DSM-5 personality traits. Assessment, 20(3), 286-294. https://doi.org/10.1177/10731911124 71141.

Babiak, P., Neumann, C., \& Hare, R. D. (2010). Corporate psychopathy: Talking the walk. Special Issue: International Perspectives on Psychopathy, 28(2), 171188. https://doi.org/10.1002/bsl.925.

Bateman, A. W., Gunderson, J., \& Mulder, R. (2015). Treatment of personality disorder. Barnet, Enfield, and Haringey Mental Health NHS Trust. https://doi.org/10.1016/s01406736(14)61394-5.

Bernerth, J.B., Armenakis, A., Field, H., Giles, W., \& Jack Walker, H. (2007). Is personality associated with perceptions of LMX? An empirical study. Leadership \& Organization Development Journal, 28(7), 613631. https://doi.org/10.1108/01437730710 823879 .

Bernerth, J. B., Walker, H.J., \& Harris, S.G. (2015). Rethinking the benefits and pitfalls of leader-member exchange: A reciprocity versus selfprotection perspective. Human Relations, 69(3), 661-684. doi: $10.1177 / 0018726715594214$.

Board, B. J. \& Fritzon, K. (2005). Disordered personalities at work. Psychology, Crime \& Law, 11(1), 1732. https://doi.org/10.1080/10683160 310001634304.

Deinert, A., Homan, A.C., Boer, D., Voelpel, S. C., \& Gutermann, D. (2015) Transformational leadership sub-dimensions and their link to leaders' personality and performance. The Leadership Quarterly, 26(6), 1095-1120 http://dx.doi.org/10.1016/j.leaqua.20 15.08.001.

Epitropaki, O. \& Martin, R. (2015). LMX and work attitudes: Is there anything left unsaid or unexamined? In T. N. Bauer \& B. Erdogan (Eds.), The Oxford handbook of leader-member exchange. Oxford University Press. doi:

10.1093/oxfordhb/9780199326174.0 01.0001 .

Ettner, S. L., Maclean, J. C., \& French, M. T. (2011). Does having a dysfunctional personality hurt your career? Axis II personality disorders and labor market outcomes. Industrial Relations: A Journal of Economy and Society, 50(1), 149-173. https://doi.org/10.1111/j.1468232X.2010.00629.x. 
Fossati, A., Somma, A., Borroni, S., Markon, K., \& Krueger, R. (2015). The Personality inventory for DSM-5 brief form: evidence for reliability and construct validity in a sample of community-dwelling italian adolescents. Assessment, 24(5), 615631. https://doi.org/10.1177/10731911156 21793.

Hengartner, M. P., Müller, M., Rodgers, S., Rössler, W., \& Ajdacic-Gross, V. (2013). Occupational functioning and work impairment in association with personality disorder trait-scores. Social Psychiatry and Psychiatric Epidemiology, 49(2), 327-335. https://doi.org/10.1007/s00127-0130739-2.

Joo, B. \& Ready, K. J. (2012). Career satisfaction: The influences of proactive personality, performance goal orientation, organizational learning culture, and leader-member exchange quality. Career Development International, 17, 276295. doi: 10.1108/13620431211241090.

Judge, T. \& Robbins, S. P. (2017).

Organizational behavior $\left(17^{\text {th }}\right.$ ed.). Pearson.

Kaiser, R. B., LeBreton, J. M., \& Hogan, J. (2013). The dark side of personality and extreme leader behavior. Applied Psychology, 65(1), 55-92. https://doi.org/10.1111/apps.12024.

Krueger, R. F., Derringer, J., Markon, K. E., Watson, D., \& Skodol, A. E. (2013). The personality inventory for DSM-5 briefform (PID-5-BF). Manuscript in preparation. https://www.psychiatry.org/File\%20 Library/Psychiatrists/Practice/DSM/ APA_DSM5_The-Personality-
Inventory-For-DSM-5-Brief-FormAdult.pdf.

Krueger, R. F. \& Markon, K. E. (2014). The role of the DSM-5 personality trait model in moving toward a quantitative and empirically based approach to classifying personality and psychopathology. Annual Review of Clinical Psychology, 10, 477-501. https://doi.org/10.1146/annurevclinpsy-032813-153732.

Le, K., Donnellan, M. B., \& Conger, R. (2013). Personality development at work: Workplace conditions, personality changes, and the corresponsive principle. Journal of Personality, 82, 44-53. https://doi.org/10.1111/jopy.12032.

Lian, H., Lance-Ferris, D., \& Brown, D.J. (2012). Does taking the good with the bad make things worse? How abusive supervision and leadermember exchange interact to impact need satisfaction and organizational deviance. Organizational Behavior and Human Decision Processes, 117(1), 41-52. https://doi.org/10.1016/j.obhdp.2011. 10.003 .

Liden, R. and Maslyn, J. (1998). Multidimensionality of Leadermember exchange: An Empirical Assessment through Scale Development. Journal of Management, 24(1), 43-72. https://doi.org/10.1016/S01492063(99)80053-1.

Ouimet, G. (2010). Dynamics of narcissistic leadership in organizations. Journal of Managerial Psychology, 25(7), 713-726. https://doi.org/10.1108/02683941011 075265. 
Schilling, J. \& Schyns, B. (2014). The causes and consequences of bad leadership. Zeitschrift Für Psychologie, 222(4), 187-189. https://doi.org/10.1027/21512604/a000185.

Schmeck, K., Schlüter-Müller, S., Foelsch, P.A., \& Doering, S. (2013). The role of identity in the DSM-5 classification of personality disorders. Child Adolesc Psychiatry Ment Health 7, 27. https://doi.org/10.1186/1753-2000-727.

Schyns, B., Maslyn, J., \& van Veldhoven, M. (2012). Can some leaders have a good relationship with many followers? Leadership \& Organization Development Journal, 33(6), 594-606. https://doi.org/10.1108/01437731211 253046 .

Sears, G. J. \& Hackett, R. D. (2011). The influence of role definition and affect in LMX: A process perspective on the personality - LMX relationship. Journal of Occupational and Organizational Psychology, 84(3), 544-564. https://doi.org/10.1348/096317910X 492081.

Thomas, K. M., Yalch, M. M., Krueger, R. F., Wright, A. G., Markon, K. E., \& Hopwood, C. J. (2012). The convergent structure of DSM-5 personality trait facets and five-factor model trait domains. Assessment, 20(3), 308311. https://doi.org/10.1177/10731911124 57589.

Webster, V., Brough, P., \& Daly, K. (2016) Fight, flight or freeze: Common responses for follower coping with toxic leadership. Stress \& Health, 32(4), 36-34. https://doi.org/10.1002/smi.2626.

Yoon, D.J. \& Bono, J.E. (2016). Hierarchical power and personality in leader-member exchange. Journal of Managerial Psychology, 31(7), 1198-1213. doi: 10.1108/JMP-032015-0078.

Zhang, Z., Wang, M., \& Shi, J. (2012). Leader-follower congruence in proactive personality and work outcomes: The mediating role of leader-member exchange. Academy of Management Journal, 55(1), 111130. https://doi.org/10.5465/amj.2009.086 5.

Zimmerman, M. (2012). Is there adequate empirical justification for radically revising the personality disorders section for DSM-5? Personality Disorders: Theory, Research, and Treatment, 3(4), 444-457. https://doi.org/10.1037/a0022108. 